International Journal of Applied Dental Sciences 2021; 7(4): 142-144

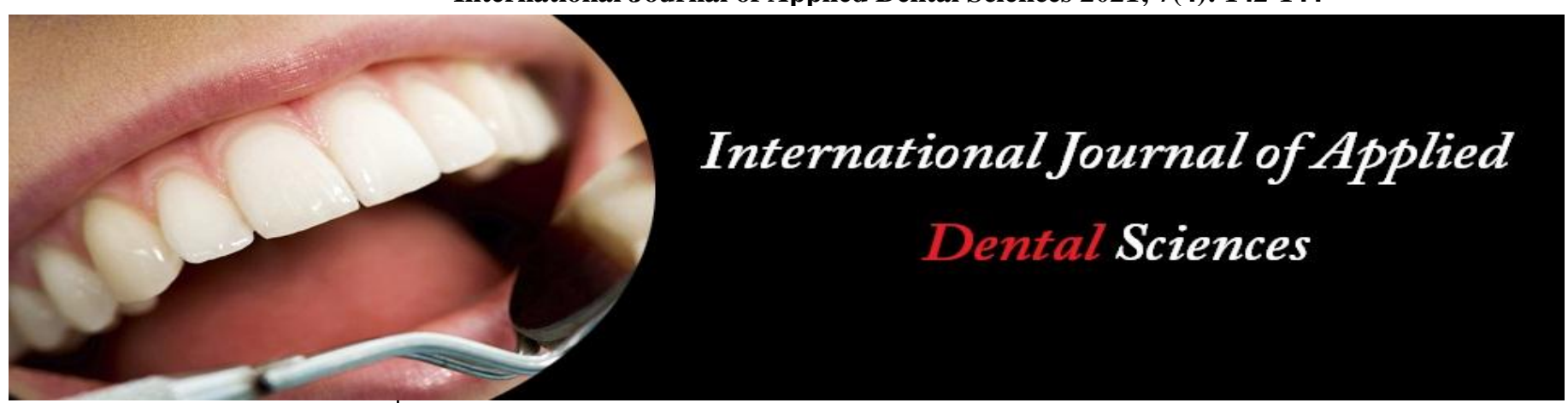

ISSN Print: 2394-7489

ISSN Online: 2394-7497

IJADS 2021; 7(4): 142-144

(C) 2021 IJADS

www.oraljournal.com

Received: 02-08-2021

Accepted: 06-09-2021

Minha Majeed Kak

Post Graduate Student,

Department of Oral \&

Maxillofacial Pathology and

Microbiology, Kothiwal Dental

College and Research centre

Moradabad, Uttar Pradesh,

India

Arya Jyoti

Post Graduate Student,

Department of Oral \&

Maxillofacial Pathology and

Microbiology, Kothiwal Dental

College and Research centre

Moradabad, Uttar Pradesh,

India

\section{Anurag Nath}

Post Graduate Student,

Department of Oral \&

Maxillofacial Pathology and

Microbiology, Kothiwal Dental

College and Research centre

Moradabad, Uttar Pradesh,

India

\section{Priyanka Rastogi}

Professor and Head of the Department, Kothiwal Dental

College and Research centre Moradabad, Uttar Pradesh, India

\section{Sachin Kumar}

Professor, Department of Oral \&

Maxillofacial Pathology and

Microbiology, Kothiwal Dental

College and Research centre

Moradabad, Uttar Pradesh, India

Corresponding Author:

Minha Majeed Kak

Post Graduate Student,

Department of Oral \&

Maxillofacial Pathology and

Microbiology, Kothiwal Dental

College and Research centre

Moradabad, Uttar Pradesh,

India

\section{Extracted human teeth for dental educational purpose: Vinegar as a disinfectant}

\author{
Minha Majeed Kak, Arya Jyoti, Anurag Nath, Priyanka Rastogi and \\ Sachin Kumar
}

DOI: $\underline{\text { https://doi.org/10.22271/oral.2021.v7.i4c.1362 }}$

\section{Abstract}

Background: Dental students routinely use extracted human teeth for preclinical and clinical procedures thus require constant handling of the same. Extracted teeth can be potent sources of blood borne pathogens and other infections thus require proper disinfection of them. Centers for Disease Control and Prevention (CDC) has adopted guidelines for infection control of extracted teeth used for research and teaching, requiring that teeth be sterilized before use. Many methods of disinfection have been proposed in literature having their own advantages and disadvantages.

Aim: To asses vinegar as disinfectant of extracted human teeth and its effectiveness in sterilization.

Material and Methods: A total of 50 extracted non-carious human teeth were sterlised both by physical methods as by Autoclaving, boiling and microwaving and chemical methods by keeping in seven disinfectant media-10\% formalin, $6.5 \%$ hydrogen peroxide, $5 \%$ sodium hypochlorite, $70 \%$ alcohol, vinegar, Betadine and normal saline. Later, teeth from each group were placed individually in separate test tubes containing $10 \mathrm{ml}$ of Brain heart infusion at $37^{\circ} \mathrm{C}$ for $48 \mathrm{~h}$ to observe the evidence of growth of microorganisms.

Results: Results were analyzed using Kruskal-Wallis test. Vinegar, 10\% Formalin, Betadine and 6.5\% Hydrogen peroxide were effective. The results were statistically significant with Kruskal-Wallis test value 30.031 with $\mathrm{p}$-value $<0.001$.

Conclusion: Vinegar can be used as an effective non-hazardous disinfectant for extracted human teeth.

Keywords: Disinfection, extracted teeth, formalin, vinegar, blood borne pathogens, hydrogen peroxide

\section{Introduction}

The basic teaching of Dentistry revolves around the tooth/teeth. From the undergraduate training to post graduate training, every student of Dentistry is directly or indirectly involved in dealing with the tooth/teeth. The basic preclinical training or clinical assignments acquired by the Dental students is on artificial tooth models, typhodont teeth and extracted human teeth. The dental procedures are best learnt directly on extracted human teeth as they best simulate the clinical situations but also exposes the dental operators to the risk of cross infections from pathogens associated with them as they can be potential source of blood borne pathogens like Human Immunodeficiency Virus (HIV), Hepatitis B Virus (HBV), Hepatitis C Virus (HCV) or other ${ }^{[1,2]}$.

Freshly extracted Human teeth are the potential source of infection and cross contamination to laboratory equipments and personal, therefore, teeth that are to be used for educational, teaching and research purposes must be decontaminated immediately after their removal [3]. Also as per the guidelines adopted by the Centres for Disease Control and Prevention (CDC) requiring the teeth be sterilized before use to minimize the risk of transmission of the blood borne pathogens ${ }^{[1]}$ various chemicals such as $10 \%$ Formalin, Sodium hypochlorite, Hydrogen peroxide and Glutaraldehyde have been tried for decades for disinfection of extracted teeth with varying success [2, 4]. The recommended methods from past for preventing cross contamination are Microwave radiation, Autoclave sterilization and Gamma radiation, but these methods are not viable for routine usage as they are laborious and time consuming. For infection control Formalin storage has proven to be effective in most of the studies but due to its carcinogenic potential it is considered a hazardous material ${ }^{[5]}$. 
A suitable alternative to formalin for storage and disinfection of extracted human teeth is therefore essential.

Infection control concerns regarding the handling of teeth for research purposes have prompted investigators to evaluate the effects of disinfection/sterilization on extracted teeth ${ }^{[6]}$. Till date only few studies have assessed the effectiveness of vinegar as a disinfectant of extracted human teeth ${ }^{[1,2]}$. Also, vinegar is non-hazardous and non-carcinogenic that is economical and a common household commodity thus easily available, the present study was conducted to evaluate vinegar as potential disinfectant for extracted Human teeth.

\section{Materials and Methodology}

The study was conducted in the department of Oral and Maxillofacial Pathology, Kothiwal Dental College and Research Centre. A total of 50 freshly extracted human noncarious and unrestored teeth due to Orthodontic and Periodontal reasons, from the Department of Oral and Maxillofacial Surgery were taken. Teeth were randomly divided into one of the following Ten groups (5 teeth per group) and were placed in $10 \mathrm{ml}$ of disinfectant solution for seven days.

Group 1 - 10\% Buffered Formalin (As Positive Control)

Group 2 - 6.5\% Hydrogen peroxide $\left(\mathrm{H}_{2} \mathrm{O}_{2}\right)$

Group 3 - 5\% Sodium hypochlorite $(\mathrm{NaOCl})$

Group 4 - 70\% Alcohol

Group 5 - Boiling water at $100^{\circ} \mathrm{C}$ for $30 \mathrm{~min}$

Group 6 - Microwave $600 \mathrm{~W}$ for $3 \mathrm{~min}$

Group 7 - Autoclaved at $121^{\circ} \mathrm{C}$ at $15 \mathrm{lbs}$ psi for $30 \mathrm{~min}$

Group 8 - Betadine solution

Group 9 - Commercially available vinegar (Nilons)

Group 10 - Normal saline (0.9\%) (As Negative Control)

After the disinfection process for a week, the disinfectants were discarded and the tooth samples were transferred into sterile Normal Saline for 1 minute. A nutrient medium (brain heart infusion broth) was prepared and autoclaved and then teeth from each group were incubated individually in separate test tubes containing $10 \mathrm{ml}$ of media at $37^{\circ} \mathrm{C}$ for 48 hours. A homogenous turbidity in few of the sample test tubes was visible after 2 days giving the evidence of microbial growth in the broth. Clear broth samples with no visible growth were considered as effective disinfectants. The results were statistically analyzed using Kruskal-Wallis test.

\section{Results}

The nutrient broth samples were observed for all the Ten groups at the end of a 48 -h period. Clear Nutrient broth samples indicated effective disinfection while the evidence of turbidity in the broth samples indicated microbial growth and hence ineffective sterilization. Kruskal-Wallis analysis of the data showed statistically significant difference in the outcomes when comparing the various methods of disinfection and sterilization [Table 1]. Out of the ten disinfectants used in the present study Groups 1, 2, 8 and 9 had higher proportion of disinfected teeth compared to other groups put together, whereas Groups 5, 6 and 10 had lesser/ negligible proportion of disinfected teeth compared to other groups put together. Betadine had excellent results but imparted colour to the sample teeth. No turbidity of the nutrient media was observed for four groups in the present study $-10 \%$ formalin, $6.5 \%$ hydrogen peroxide, Betadine and vinegar. All the samples in the normal saline and boiling water group exhibited turbidity in the nutrient broth. Of the ten disinfectants used in the present study, $10 \%$ formalin, $6.5 \%$ hydrogen peroxide, Betadine and vinegar disinfected all the teeth. The results were highly significant statistically with $\mathrm{H}$ value of 30.031 and $p<0.001$.

\section{Discussion}

Extracted Human teeth are frequently required in dental education from pre-clinical to clinical work and are thus collected for the same. Adequate care is therefore must for the dental personnels while handling them as they can harbor pathogens and can be potent source of blood borne pathogens including $\mathrm{HIV}, \mathrm{HBV}, \mathrm{HCV}$ and bacterial pathogens that may exist in pulp, radicular and periradicular tissue. Thus for the minimal spread of infection and safe usage of these extracted teeth, it is necessary to subject them to adequate and effective disinfection / sterilization and proper storage to ensure they are free of biological residues ${ }^{[7]}$.

In the present study disinfectants like Vinegar, 10\% Formalin (control), 6.5\% Hydrogen Peroxide $\left(\mathrm{H}_{2} \mathrm{O}_{2}\right), 70 \%$ Alcohol, Betadine and $5 \% \mathrm{NaOCl}$ and other procedures such as Microwaving for $3 \mathrm{~min}$ at $160 \mathrm{~W}$, autoclaving for $30 \mathrm{~min}$ at $121^{\circ} \mathrm{C}$ and $15 \mathrm{lbs}$ pressure, immersion in boiling water for 30 $\min$ at $100^{\circ} \mathrm{C}$ were used for disinfection of the extracted teeth and normal saline taken as a negative control. Among all the disinfectants used Vinegar, 10\% Formalin, 6.5\% Hydrogen peroxide and Betadine were found to be effective in disinfecting all the tooth samples when immersed in them for seven days.

Vinegar is a liquid consisting mainly of 5\% acetic acid $(\mathrm{CH} 3 \mathrm{COOH})$ and water which crosses the bacterial cell membrane and denatures the proteins and fats causing release of protons leading to cell death. The results of this study were in accordance with Tijare et al. ${ }^{[1]}$ and Gogineni S et al. ${ }^{[2]}$, who reported that vinegar could be used as storage and disinfectant medium for extracted human teeth.

$10 \%$ Buffered Formalin was used in this study and proved to be an effective disinfectant of extracted human teeth and the results were consistent with the previous studies ${ }^{1-4}$. Formalin is composed of methyl alcohol, formaldehyde and sodium acetate as aqueous solution that preserves the tissues by cross linking proteins, glycoproteins, nucleic acid and polysaccharides to form insoluble products with methylene bridge ${ }^{[2,8]}$. Being an effective disinfectant, Formalin is also a potential carcinogen, thus should be handled with care rather avoided.

Our study showed that $6.5 \% \quad \mathrm{H}_{2} \mathrm{O}_{2}$ was effective in disinfecting all the samples when immersed for a week as it has good bactericidal property which was in support with Tijare et al. ${ }^{[1]}$ and Gogineni $\mathrm{S}$ et al. ${ }^{[2]}$.

$5 \% \mathrm{NaOCl}$ was not effective in disinfecting all the tooth samples and caused the tooth damage. $\mathrm{NaOCl}$ is composed of sodium and hypochlorite dissolved in water and is commonly known as bleach and is frequently used as disinfectant or a bleaching agent. Similar observations were noted by Tijare $e t$ al. ${ }^{[1]}$ and Gogineni $\mathrm{S}$ et al. ${ }^{\text {[2] }}$ who also in their studies reported that Sodium hypochlorite may increase enamel porosity and alter dentin structure nullifying the use of teeth stored in this solution ${ }^{[9,10]}$. Betadine is the formulation of povidine iodine / iodopovidone, a chemical complex of povidone, hydrogen and iodine that is basically an antiseptic for topical disinfection. In this study, all tooth samples immersed in Betadine were effectively disinfected thus giving positive results with the only drawback of imparting its color to the tooth samples. No study so far has been done using 
Betadine for the purpose of disinfecting extracted tooth samples.

For past many years, Autoclaving is considered as the gold standard method for sterilization and disinfection. Using this technique at different temperatures have proved this to be the most effective method for disinfection ${ }^{[2,4]}$. In the current study, autoclaving for $30 \mathrm{~min}$ at $121^{\circ} \mathrm{C}$ and $15 \mathrm{lbs}$ pressure was not $100 \%$ but $80 \%$ effective, which could be due to some technical errors.
Boiling the samples in water for $30 \mathrm{~min}$ at $100^{\circ} \mathrm{C}$ didn't prove to be effective in disinfecting the tooth samples. Similar results have been observed in previous studies as well ${ }^{[2,4]}$.

Vinegar proved to be $100 \%$ effective in disinfecting all the extracted teeth and also superior to other disinfectants. Being non-carcinogenic, economical and eco-friendly, its use is advantageous for the Dental students and researchers as it is simple to use, as the teeth are just required to be kept immersed in the solution in a closed container.

Table 1: Depicting the efficacy of different disinfectants in relation to Microbial growth

\begin{tabular}{|c|c|c|c|c|c|c|}
\hline Groups & Disinfectant & Sample teeth & Duration (Days) & Number of teeth disinfected & H value & p-value \\
\hline Groups 1 & $10 \%$ Formalin & 5 & 7 & 5 & \multirow{10}{*}{30.031} & \multirow{10}{*}{$<0.001(\mathrm{HS})$} \\
\hline Groups 2 & $\mathrm{H}_{2} \mathrm{O}_{2}$ & 5 & 7 & 5 & & \\
\hline Groups 3 & $\mathrm{NaOCl}$ & 5 & 7 & 2 & & \\
\hline Groups 4 & Alcohol & 5 & 7 & 1 & & \\
\hline Groups 5 & Boiling Water & 5 & $30 \mathrm{~min}$ & 0 & & \\
\hline Groups 6 & Microwave & 5 & $3 \min$ & 1 & & \\
\hline Groups 7 & Autoclave & 5 & $30 \min$ & 4 & & \\
\hline Groups 8 & Betadine & 5 & 7 & 5 & & \\
\hline Groups 9 & Vinegar & 5 & 7 & 5 & & \\
\hline Groups 10 & Normal saline & 5 & 7 & 0 & & \\
\hline
\end{tabular}

\section{References}

1. Tijare M, Smitha D, Kasetty S, Kallianpur S, Gupta S, Amith H. Vinegar as a disinfectant of extracted human teeth for dental educational use. J Oral Maxillofac Pathol 2014;18:14-8.

2. Gogineni S, et al. Evaluation of Vinegar as a Disinfectant for Extracted Human Teeth - An in-Vitro Study. J Clin and Diag Res 2016;10(7):50-2.

3. Loyalekar NV, Bhat VS, Bhat SS. Disinfection methods of extracted human teeth. J Oral Health Comm Dent 2007;1:27-9.

4. Kumar M, Sequeira PS, Peter S, Bhat GK. Sterilization of extracted human teeth for educational use. Indian J Med Microbiol 2005;23:256-8.

5. Viana PS, Machado AL, Giampaolo ET, Pavarina AC, Vergani CE. Disinfection of bovine enamel by microwave irradiation: Effect on the surface micro hardness and demineralization/remineralization processes. Caries Res 2010;44:349-57.

6. DeWald JP. The use of extracted teeth for in vitro bonding studies: A review of infection control considerations. Dent Mater 1997;13:74-81.

7. Albrecht L, Ferreria E, Passos M. Teeth processing in human teeth bank proposal of protocol. RSBO 2013;10(4):386-93.

8. Attam K, Sangeeta T, Seema Y, Sanjay M. Effect of autoclaving and formalin storage on extracted teeth. J Conserv Dent 2009;12:26-30.

9. McGuckin RS, Pashley DH. Effect of disinfection/sterilization treatments on gluma-mediated dentin shear bond strengths. Am J Dent. 990;3:278-82.

10. Moura JS, Rodrigues LK, Del Bel Cury AA, Lima EM, Garcia RM. Influence of storage solution on enamel demineralization submitted to $\mathrm{pH}$ cycling. J Appl Oral Sci 2004;12:205-8. 